\title{
Why has burglary declined by over 80 percent across four decades in the United States? Evidence relating to the security hypothesis
}

\author{
Graham Farrell ${ }^{1}$
}

\begin{abstract}
Residential burglary imposes significant financial and emotional costs upon victims and society overall. Yet residential burglary in the US has declined by over 80 percent across the last four decades, representing a major social phenomenon that remains largely unexplained. International research indicates a need for investigation of the security hypothesis. Here, 50 years of burglary studies are examined chronologically. A consistent narrative emerges which indicates that household security, largely absent in the 1970s, improved gradually over time. Improvement occurred via three mechanisms: the increased prevalence, quality, and routine use of security fixtures and fittings. In addition, crime displacement declined as fewer household presented easy crime opportunities, and burglars' average age increased ( juveniles finding burglary increasingly difficult). The likelihood that 50 years of diverse evidence points in the same direction by chance, and without significant contrary evidence, seems remote. Hence the conclusion is that gradual household security improvements played a central role in the decline in residential burglary over time. Implications for theory, policy, and further research are identified.
\end{abstract}

\footnotetext{
${ }^{1}$ School of Law, University of Leeds. g.farrell@leeds.ac.uk
} 


\section{Introduction}

Residential burglary imposes significant financial and emotional costs on victims, their families and friends, and on society in general (Brown and Harris 1989; Shover 1991; Winkel and Vrij 1993, Miller, Cohen and Wiersema 1996, Cohen 2000, Beaton, Cook, Kavanagh and Herrington 2000, Wickramasekera, Wright, Elsey, Murray and Tubeuf 2015). The monetary costs include the replacement of stolen goods, repairs to damaged property, and the cost of the time to organize those activities. The monetary costs are often exceeded by the non-monetary emotional and psychological costs to individuals and families of the intrusion and trespass. This violation and defilement of their property results in anger, shock, fear and difficulty sleeping (Budd 1999). The additional costs to society include the monetary costs of policing, criminal justice and private precautionary responses, health and psychological services, and the non-monetary cost of the fear of crime engendered. Further, there are numerous cost multipliers from precursor and subsequent crimes. This can include theft of a vehicle for travel to commit a suburban burglary and transport stolen goods. Burglary can also escalate when household occupants are present, and can result in assault and rape, with Shover (1991:78) concluding that " $[\mathrm{t}]$ he potential for physical harm to its victims places burglary near the top of offenses most feared by its citizens". Burglary cost are also multiplied via the further damage to society caused by re-sale markets for stolen goods, illicit drug markets that are funded by the proceeds of burglary, as well as violence associated with those markets (Felson and Clarke 1998). Longer-term costs are also incurred due to the progression along criminal careers that can occur when juveniles succeed in burglary (Owen and Cooper 2013), and due to the reduced employment and life prospects experienced by crime victims (Macmillan 2000).

Investigating two decades of increasing burglary rates following the Second World War, the 1967 President's Commission on Law Enforcement and the Administration of Justice concluded that

"People can do much to insure their own safety and that of their families and belongings by reducing the opportunities for crime. Many crimes would not occur if individuals had proper locks on their doors and windows and enough lighting to discourage prowlers..."

(President's Commission on Law Enforcement and Administration of Justice, 1967; 288)

The six-fold increase in the residential burglary rate from the 1940s to the 1970s brought further attention, a subsequent Bureau of Justice Statistics (BJS) report concluding that:

"Household burglary ranks among the more serious felony crimes...[B]urglary is potentially a far more serious crime than its classification as a property offense indicates; for many victims, including those that avoid the trauma of personal confrontation, the invasion of their home on one or more occasions constitutes a violation that produces permanent emotional scars." (Bureau of Justice Statistics 1985; 1)

Another BJS report put burglary 'at the heart' of America's crime problem:

"Robbers and burglars exact heavy losses and suffering from their victims. The most numerous of the offenses that the public considers to be the most serious, many robberies and burglaries also fund illegal drug purchases. A cogent argument can be made that controlling the incidence of these two crimes would strike at the heart of criminal behavior in the United States." (Perez 1992; 1) 
and a third categorized burglary as of 'high national concern':

"Of the crimes measured by the NCVS [National Crime Victimization Survey], many people find burglaries and violent crimes committed by strangers to be especially threatening. For the purposes of this report, these crimes have been termed crimes of high concern." (Bastion 1992; 8, emphasis in original)

By that time, however, the burglary rate was already in decline. And the decline continued such that, at the time of writing, it has been the dominant trend for between four and five decades (Rand, Lynch and Cantor 1997, Walters et al. 2013; Figure 1). Burglaries per household recorded by the police as the Uniform Crime Reports (UCR) declined 81.9 percent between 1980 and 2019. The National Crime Victimization Survey (NCVS), which includes crimes not reported to the police, estimates an 83.0 percent decline between 1980 and 2019, or 84.6 percent if 1974 is taken as the reference year (Figure 1$)^{1}$.

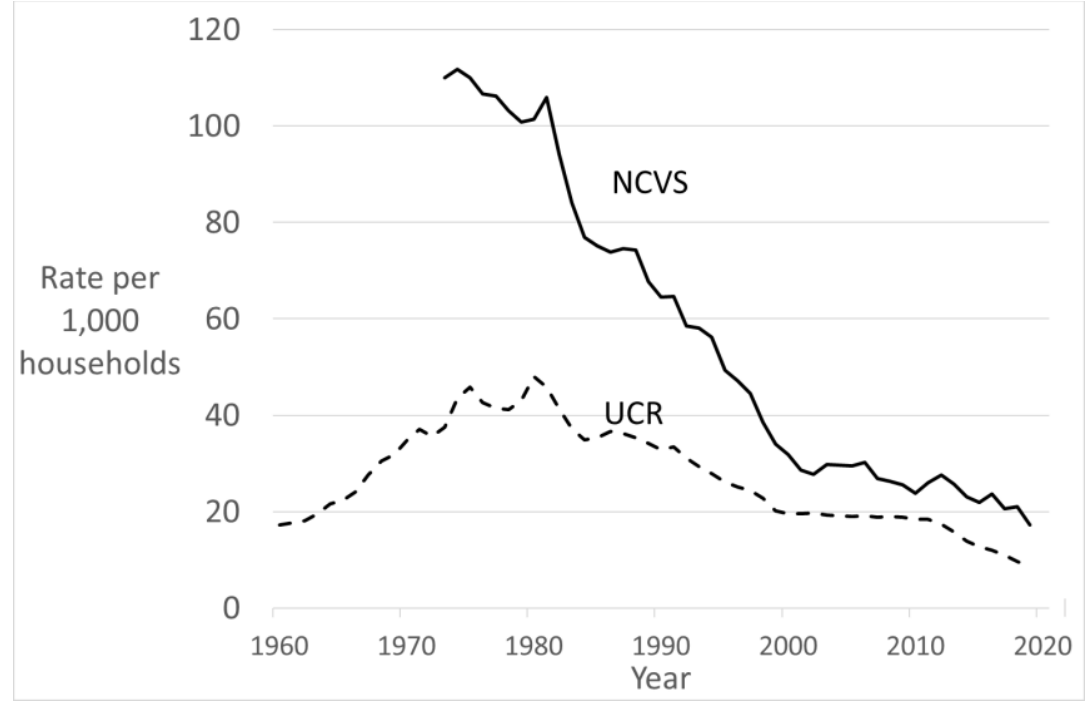

Figure 1. Burglaries per 1000 households (Sources: NCVS, UCR, US Census)

A lack of research seeking to explain the decline in residential burglary was apparent two decades ago, when a National Institute of Justice researcher, writing in this journal, observed that "In contrast to the media and scholarly interest given to the recent drop in homicide rates and other violent crimes has been [an] almost complete lack of attention paid to the 25 -year decline in US residential burglary rates..." (Titus 1999; 60). Some more recent studies of the violent crime drop do examine burglary. However, they largely focus on the violent crime drop from the early to mid-1990s when violence peaked, overlooking how burglary declined from the 1970s or early 1980. Further, most such attempts to explain the crime decline from the 1990s have been found lacking: There is little or no sound evidence to uphold propositions that crime declined due to, for example, increased imprisonment, changes to policing, changes to abortion law, illicit drug markets, demographic change, childhood lead poisoning, and so on, and so such hypotheses are not the focus here because they are taken to have been largely falsified (Farrell 2013; Farrell, Tilley and Tseloni 2014). 
The focus here is the security hypothesis, for which there is significant supporting evidence in relation to the international crime drop for other crime types and countries. A series of international studies find that crime declined because of security improvements, and did so without much, if any, crime displacement. The evidence is largely unequivocal in relation to vehicle crime, with strong corroborating evidence from Australia, England and Wales, Germany, the Netherlands, and to some extent the US. Improvements to vehicle security, particularly the electronic immobilizer and door deadlocks, were responsible for the decline in auto theft in those countries (Kriven and Ziersch 2007, Bässmann 2011, Farrell et al. 2011, Fujita and Maxfield 2012, Brown 2015a, 2015b, van Ours and Vollaard 2016, Dixon and Farrell 2020). The role of various types of household security devices in declining residential burglary has not been subject to as much empirical study, but the existing work of most relevance is a series of British studies. These studies are discussed in more detail later but conclude that household security improvements, particularly improved door and window locks and security lighting, are largely responsible (Tilley et al. 2011, 2015a, Tseloni et al. 2016, 2017). The British studies benefitted from the Crime Survey for England and Wales which collated several decades' information on household security device usage. Such information has not, to our knowledge, been collected in national victim surveys relating to the United States. There are, however, research studies on the US and elsewhere which contain some information about household security. The present study seeks to identify and synthesize that information. So this study aims to piece together the picture from five decades of diverse burglary studies.

The main theoretical reference points for this study are routine activities and rational choice, situational crime prevention and the security hypothesis. However, once these have been introduced briefly in this section, the focus is mainly on the evidence. The routine activities perspective indicates the importance of target suitability, the capability of guardians, and how often and where they converge with potential offenders in order for crime to occur (Cohen and Felson 1979). Offender decisions operate within the framework of bounded rationality (for collections see Clarke and Cornish 1986; Piquero and Tibbetts 2002), which means that offenders take crime opportunities when they perceive benefits to outweigh costs. Offenders' perceptions are subjective, and the costs and benefits of crime include monetary and nonmonetary components. The perceived costs of committing residential burglary include the time and effort required, the risk of arrest and punishment, the risk of bodily harm if interrupted, plus any possible emotional costs such remorse. The perceived benefits include the monetary gain from stolen cash and fenced goods but also the benefit from excitement and feelings of power that some burglars report (Nee and Meenaghan 2006). Situational crime prevention identifies mechanisms by which crime is made more costly or less beneficial (Clarke 2012, 2017), and the mechanisms by which different security devices work are here interpreted within this framework. For the most part, household security devices trigger mechanisms that make burglary actually, or perceived to be, more difficult or riskier. Stronger window frames and locks, for example, harden the target and reduce access to a property, requiring time, effort and skill on behalf of offenders to overcome, or additional time and effort to identify a less secure property. Security lighting deters because it threatens detection, making residential burglary riskier, and so on (Sorensen 2003).

The main finding of this study is that there is good preliminary evidence of gradual long-term improvements to household security over time. A set of key factors that inform the understanding of how and why change occurred are also identified. The combination of the 
various aspects of evidence and its strong fit with the theory lead to the conclusion that gradual household security improvements caused the gradual long-term decline in residential burglary.

\section{Method}

The study collates information from previous studies of burglary and household security, and includes some supplementary analysis of burglar arrest data. Burglary studies that focus on security were identified through electronic literature searches, close examination of key burglary studies (particularly the major book-length studies), and from references in existing studies. However, it was soon apparent that household security is seldom mentioned in the title, abstract or keywords of burglary studies, and often comprises a secondary or tertiary concern. That is, in many of the major studies of burglary, including the majority of books on the subject, household security may form part of the study to varying degrees but is not the main focus. Hence these studies were examined to identify their components which relate to household security, and to identify potentially relevant further studies.

The supplementary analysis of trends in age-related burglar arrests uses data for 1980-2014 from the Bureau of Justice Statistics online arrest data tool (Snyder, Cooper and Mulako-Wangota 2017), and data from 1960 to 1979 as supplied by the FBI (see acknowledgements for details). It is generally accepted that, other things equal, trends in arrests are a reasonable indicator of those in offending, and there are significant precedents for using the data in the way it is used here (e.g. Blumstein, Cohen, Roth and Visher 1986, Farrington 1986, Snyder 2012).

Since the issue of security is often secondary or, for present purposes, 'hidden' within burglary studies that have a different primary focus, the possibility that some useful studies were not captured cannot be excluded. To that end, the corresponding author welcomes suggestions and critical comment. Methodologically, however, the key issue is whether the captured studies offer a representative picture of the history of US residential burglary and security. With respect to that issue, since the evidence comes from multiple sources and methods spanning 50 years, and appears to point in the same general direction, this affords some confidence in the representativeness of the findings. That said, it is clear that the subject will benefit greatly from further research, some possibilities to that end are discussed later, and if the present study spurs further research on the topic then it will have achieved one of its aims.

\section{The Extent and Effectiveness of Household Security}

A major study of 18 areas of Boston in the early 1970s specified that, for a door to be defined as secure, for purposes of the study, it must "(1) be of metal, metal panels, solid wood, or hollow wood of three-quarter inch thickness, (2) have no unprotected glass near the door handle; (3) have no exposed hinges; (4) lock with either a three-quarter inch dead latch or dead bolt or a vertical bolt." (Reppetto 1974, 67). Only 8 percent of households were found to have secure doors. That is, over 90 percent of households had at least one insecure door because "39 percent ... were constructed of wood panel, 26 percent .. had glass near the door handle, 8 percent [had] removable exterior hinges, and the remainder ... inadequate locking systems." (p.67). Despite this, "burglary incidence did appear inversely related to ... door security.." in middle class areas (p.68). The reason the study could not assess the effectiveness of other specific security measures 
is particularly telling: There were too few to evaluate! (p.69). The study is generally considered a landmark in the field, and its significance here is to lay a methodologically strong foundation to conclude that good quality household security was extremely scarce at that time.

With respect to burglars, the Boston study found that "only $6 \%$ could be rated as skilled. The typical burglar was young (under 25) and opportunistic. Thus, he relied on simple tools and techniques to attack his target." (Reppetto $1984 ; 157)$. This squares with a Canadian review's contemporary finding that "The notion that residential burglars employ relatively unskilled types of modus operandi is consistent with the youth and inexperience of most persons committing burglary." (Waller and Okihiro 1978; 26). Unskilled burglary by youths is an important indirect indicator of the absence of good quality household security.

A landmark burglary book of the 1980s found that

"The most commonly used technique over the years is to "jimmie" a lock or window. All that is required is a door or window that does not have a burglar proof lock and has a little play or give in it. In the case of a window, the burglar will work the window up and down until the fastener begins to loosen. A screwdriver or prybar might be used for extra leverage." (Rengert and Wasilchick 1985; 91).

This identifies three important factors: the absence of security, its inadequacy, and its lack of use. The study reported that "It takes just several minutes or less for a burglar to walk through an unlocked door and walk out with valuables... Another less obvious form of carelessness is to leave the door of an attached garage open after leaving home in the car." (p. 90). However, where good quality security existed it was found effective, such that

"most of the burglars we interviewed are easily discouraged by a tough lock. With so many opportunities, many burglars will move on rather than struggle with a deadbolt lock." (Rengert and Wasilchick 1985; 90).

This 'moving on' by burglars when faced with good quality security identifies a further important factor: it implies a high rate of crime displacement at that time. Most households were insecure, so there were plentiful alternate targets, which meant displacement was the easy option.

In the early 1980s, 42 percent of burglaries nationally took place without a forced entry (Bureau of Justice Statistics 1983; 3), suggesting entry points that were either without security, left open or unlocked. In line with this, Shover observed that "the world affords abundant poorly protected opportunities for burglars", drawing on the finding that only "seven percent of [1980s] households had a burglar alarm" and these "worked properly less than half the time" (Shover 1991; 83). He also suggests that burglary required little expertise at the time, when discussing a New York City study finding that "in more than half the incidents the burglars' entry was either unforced or was gained simply by breaking a window or a lock." (Shover 1991; 84). The fact that Shover groups unforced entry together with breaking a window or lock strongly implies that break-in was trivially easy: so easy that it is almost indistinguishable from unforced entry.

That is, each of these studies contribute to an emerging consensus that the low prevalence, quality and use of household security plus the ease of crime displacement, were important factors at this time. 
A New York State household survey conducted in 1983-4 considered a wide range of area and household variables relating to guardianship and security. It used multivariate models to assess the effects of occupancy and security upon burglary and attempted burglary (Garofalo and Clark 1992). It found that "Attempted door entries were less likely to succeed when locks were in use, when special outdoor lighting was used, and when the doors were visible to neighbors or from the sidewalk", and that "a locked door is the most important factor in thwarting an offender who tries to enter a single-family housing unit via a door." (p.457). In the absence of occupants, the study found that security "such as locks, lights, and timers" was the most effective measure (p.460). It also found the concurrent use of several measures was more effective. Overall this study suggests that, while rare, good quality security that was used was effective. The importance of this study is that, whereas other studies discussed so far evidenced the absence of security, this study (along with that of Reppetto 1974) showed the protective role of good quality household security. It also emphasized the role of the use or activation of that security through use of terms such as a 'locked' door rather than solely noting how many doors were fitted with locks.

A subsequent cross-national comparative study of burglary up to the mid-1980s identified a higher burglary rate in the US than in Canada or the UK (Mayhew 1987). It speculated that this reflected unforced entries when doors and windows were left open in the summer due to higher temperatures and humidity in many US states (p.46). This study thereby also suggests the importance of not just the presence but the routine use of security measures. Similarly, Winchester and Jackson's (1984) reported that " $22 \%$ of the respondents admitted that on the last occasion they had left the house empty during the day they had left at least one door or window open." (p. 8). This study identified the importance and limitations of partial security coverage, noting that:

"There is no reason to think that partial security will be any more effective in preventing residential burglary than no security at all. Securing all doors into the house with mortice locks may for example provide no protection against burglary if a window is left open or protected by nothing more than a simple catch." (Winchester and Jackson 1984; 9)

British burglars at this time were found to be largely undeterred by visible security measures because they were easily overcome (Maguire and Bennett 1982). This was confirmed by a more extensive follow-up study which revealed that even when a household had locks, seven in ten burglars were not deterred because those locks were easily overcome. Further, and consistent with the findings of Rengert and Wasilchick discussed above, the remaining offenders reported that they typically displaced to another household because of the widespread availability of targets without locks (Bennett and Wright 1984). ${ }^{2}$ Note, however, that those offenders who displaced also reported avoiding 'Chubb locks', 'special' and 'difficult' locks (p. 83). Therefore this also strongly suggests the importance of the quality of security measures, locks specifically, and its impact upon offender decision-making relating to both target selection and displacement. A major study of US burglars conducted in the late 1980s also reported that "nearly one half of the burglary sites in the present study were entered through open or unlocked windows and doors." (Cromwell, Olson and Avary 1991; 31), though such information is difficult to interpret unambiguously without additional information on the prevalence of household security.

The burglary rate had declined significantly by the time Wright and Decker (1994) conducted their classic study of experienced St. Louis burglars. They interviewed expert burglars rather 
than the juvenile novices that had characterized burglary in previous years. These experts not the effect of good quality security on their decision-making, one reporting that

"I don't do dead bolt locks because sometimes you have to kind of kick the door, loosen it up. I don't really like playing with dead bolts cause it takes too long. On picking locks, you can't really pick a dead bolt lock.” (Burglar 103, in Wright and Decker 1994; 122)

and another that

"I wouldn't mess with a house that has storm windows. I'm not gon say I've never done a house with storm windows, but it just takes more time tryin' to do two windows.'(Burglar 14 in Wright and Decker 1994; 98)

This is a reference to double-paned windows being more difficult to break, and it is likely that such windows also had stronger frames and a higher proportion of built-in locks. The insights provided by the St. Louis expert burglars are informative. First, the statements tends to suggest that security measures now played a prominent role in burglar decision-making. Second, if expert burglars were deterred by good quality door and window security, we can reasonably infer a greater effect upon youthful novices. The St. Louis study concludes that:

"The burglars seemed more unwilling than unable to overcome such obstacles; they just did not want to take the extra time and effort required. Since they were under pressure to act as quickly as possible, this makes sense. Add to this the fact that those who search for burglary sites with the intention of offending "there and then" have no foolproof way to predict the likely payoff, and the aversion to well-protected places is more sensible still. Why should they invest extraordinary energy where the reward cannot be guaranteed?" (Wright and Decker 1994; 98)

This shift in emphasis squares with the burglary rate having declined a third between 1980 and 1990 (36 percent). The St. Louis expert burglars demonstrate an aversion to deadbolts and storm windows, that is, good quality security, and the prominence of these statements is consistent with increases in the prevalence, quality and use of household security.

Research-based knowledge about the importance and role of household security has improved over time. Security improvements to already-burglarized household were found effective as part of a package of measures in the 1980s (Pease 1991; Mawby 2001), a finding corroborated by a number of studies in different developed countries through the 1990s and early 2000s (Grove et al. 2012, Bowers and Johnson 2017). A Dutch study concluded that burglar-proof windows and doors reduced burglary by a quarter in the Netherlands from 1999 (Vollaard and van Ours 2011). A study of a

By the early $21^{\text {st }}$ century, a review of residential burglary published by the Office of Community Oriented Policing Services concluded that household security could be effective, and that:

"Target-hardening makes getting into houses more difficult for burglars, and includes installing the following: sturdy doors with dead bolts; window locks, rather than latches; doublepane, storm or divided light windows, or laminated glass that is forced-entry resistant; pin locks on windows and sliding glass doors; and sliding glass door channel locks or slide bolts. ... Door security may be influenced as much by the door's sturdiness 
as by its lock. Regardless, residents should use, rather than simply install, security devices." (Weisel 2005; 28)

A relatively recent quantitative analysis of victim survey data shows that physical security measures such as door and window locks are closely linked to households with lower burglary rates (Budd 1999). A review of statistical modeling of burglary in the US reported that

"physical protection (i.e., "hardening") of homes, including locking doors, installing alarms, and light timer devices, have also been shown to correlate with burglary victimization (Miethe and McDowall, 1993; Miethe and Meier, 1990, 1994; Wilcox Rountree and Land, 1996, Wilcox Rountree, Land, and Miethe, 1994).” (Wilcox, Madensen and Tillyer 2007; 774).

The same study added to knowledge in this area by examining four aspects of guardianship, of which physical protection was one. Its findings indicated that target hardening measures and defensible space were the most effective measures, and that household's physical security measures were more effective in residential areas where a greater proportion of households had similarly high levels of household security (p. 794). This is consistent with the possibility that offenders are more likely to displace in areas with a higher level of insecure households, maintaining the burglary rate. It suggests there may be a tipping-point proportion of secure households beyond which offenders are unlikely to initiate or continue a search. ${ }^{3}$

A quantitative analysis of anti-burglary devices found that "combinations [of security devices] with door and window locks plus external lights or security chains confer at least 20 times greater protection against burglary with entry than no security." (Tseloni et al. 2016; 646). The international study of direct relevance here concluded that the decline in burglary in England and Wales from the early 1990s was attributable to the spread of insulated windows with doublepaned glass, stronger frames and integrated locks, and to the spread of interior and exterior security lighting. Three main factors were identified as responsible for the decline in burglary. First, there was a rapid decline in the prevalence of households without any security devices. Second there was an increased use of good quality, that is, effective, security devices, particularly door and window deadlocks and security lighting. Third, there was greater use of combinations of such devices and this was found to confer disproportionate protection (Tilley et al. 2015a; Tseloni et al. 2017). Note, however, that the effects of different security devices were found to vary greatly, including the finding that household alarms were ineffective in recent years (Tilley et al. 2015b), consistent with the established fact that most alarm activations are false (Sampson 2007). Cross-national analyses of the International Crime Victims Survey had earlier shown that many European countries with declining burglary had increased rates of household security (van Dijk 2008; Sorensen 2003). Overall, while the timing and rate of spread of security differs between the US and Europe, as might be expected in different countries with different housing stock and differing burglary problems, there is a great deal of consistency in the international evidence from burglary studies.

Relatively recent interviews with expert burglars found that "Around half of our sample of burglars in 2006 had noticed increased security measures taken by householders in recent years, but the most common method of entry to their most recent target had been through an open window or door." (Nee 2015; 58). The low rate of burglaries at the time of the study suggests that by the 2000s, open doors and windows were rare, that even the older expert burglars had resorted to entering only through much sought-after open windows and doors, and that closed 
windows and doors were too secure even for experts (indicating good quality security devices in routine use). These findings resonate with the views of offenders in Australia who reported that security improvements were the most likely explanation for the property crime decline in that country (Brown 2015).

Consistent with earlier studies, recent research finds offenders aware of cues indicating the age and quality of physical security measures. There are indications that expert burglars recognize the changes to household security that have taken place over time, one reporting "That [lock] would be easy. The lock on that door looks like an old one. The newer ones have thicker handles around them and are harder to get through." (Armitage 2018; 296). In contrast, and also consistent with earlier findings, the same expert burglars reported burglar alarms were not a deterrent.

A study of burglaries that occurred between 2001 and 2005 in Newark, New Jersey, compared the location of burglaries and alarms (Lee and Wilson 2013). Both were found to be spatially concentrated but without significant overlap. Lee and Wilson interpret the lack of overlap as reflecting the effectiveness of alarms in reducing burglary and causing a spatial shift in burglary patterns such that it remained primarily in non-alarmed areas. In related research, surveillance and physical security were the design factors mentioned most by burglars (Armitage and Monchuk 2011, Armitage 2013).

Gated communities have been found to be diverse in nature but generally to reduce burglary (Addington and Rennison 2013). However, while the spread of gated communities may have reduced local burglary rates, they span a relatively low proportion of the residential population and so are unlikely to have contributed much to the aggregate burglary decline in US residential burglary across the 1980s and 90s. A more recent north American study found that spatial change in the distribution of burglaries, particularly that linked to buildings with entry key fobs, was consistent with that expected as the result of improvement to home security technologies. Specifically, it used "a spatial data signature between perceived access to home security technologies and declines in residential burglary to support the security hypothesis. (Hodgkinson and Andresen 2019; 98).

Smart household security is becoming more prevalent at the time of writing. A small but growing number of households includes a suite of smart security with remote control and monitoring and remote video internally and for arrivals at the door, coordinated via smartphone apps. A review notes that household smart locks

"let you receive alerts and track who's entering and leaving your abode; email limitedaccess digital "keys" to visitors, children, trusted service workers or guests when you're not home; and remotely lock and unlock when you're away from home. .. [Y]ou could program a night mode action that locks the doors and also turns off the lights and closes the shades .If a friend, family member or service worker rings your smart doorbell while you're away, you can visually confirm who it is via the smart doorbell, then remotely unlock the door to let them in." (Wolpin, 2016)

Since experienced burglars often undertake checks for occupancy by knocking on the door, remote conversation may disrupt such checks, or at least provide photographic evidence of who arrived at the door. Manufacturers of smart household security also need to beware of interception, breach and hacking (Thomson 2016). That is, continued iterations of household 
security need to be secure to avoid adaptation by burglars that could result in renewed offender interest in household burglary. However, while we might hope that such recent developments may consolidate declines in burglary, they are too recent to have played a role in the longer-term decline.

\section{The Population of Burglars}

So far it has been shown that, when homes were insecure in the 1960s to 80s, burglars required little skill or experience. Most burglars were young. This section examines age using arrest data from the BJS and FBI, drawing on previous studies that show the decline in burglary was disproportionately a decline in adolescent offending (Butts 2000; Snyder 2012).

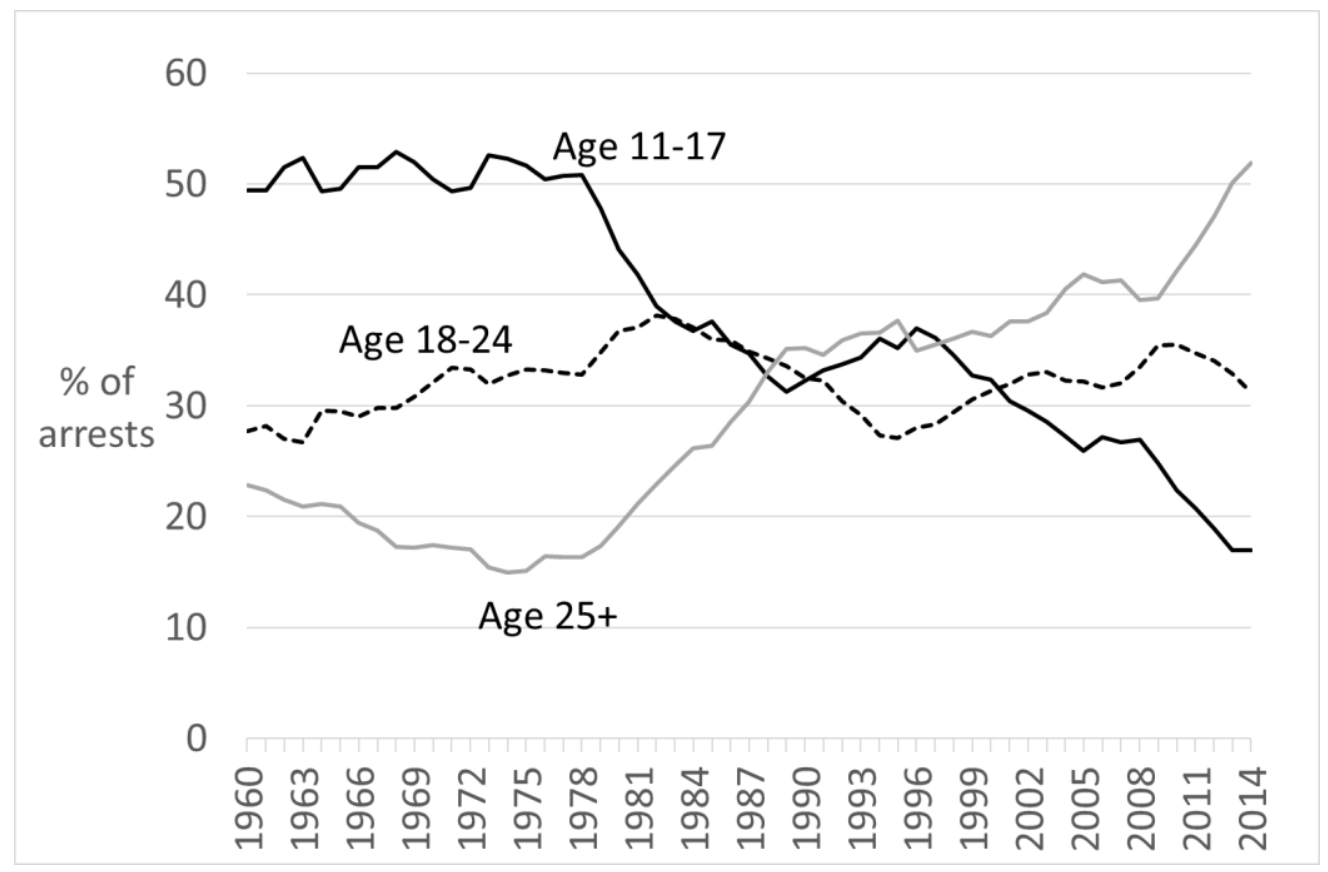

Figure 2. Burglary arrests by age group 1960-2014 (Source: BJS, FBI)

Figure 2 shows how, across the years that burglary declined, there was an increase in the proportion of older, and a decrease in the proportion of younger, burglars. It is consistent with the less experienced burglars, who are younger on average, being more easily deterred. As household security improved over time, the proportion of younger burglars decreases. By the late 2010s, the average burglar was significantly older and more experienced. This is consistent with the studies discussed earlier that found burglars nowadays have to spend much more time and effort to locate an insecure property.

The importance of the long-term change in age of burglars is straightforward. It provides a single over-time indicator spanning the decades of interest which corresponds with the other evidence. 


\section{Discussion}

The primary justification for this study was the absence of reliable explanation for a major social phenomenon: the four-decade and over 80 percent decline in US residential burglary. The study's contribution is to provide an explanation, based on significant supporting evidence, to fill the gap in knowledge. The study identified a clear over-time progression in the narrative relating to burglary and security. In the 1970s, household security was sparse and ineffective whereas by the 2000s there was more and better security. The first two columns of Table 1 summarize aspects of household security of the 1970s and 80s that were identified as important. First, the prevalence of security used to be low and few households had much if any security (Reppetto's 1974, Bureau of Justice Statistics 1983, Winchester and Jackson 1984, Rengert and Wasilchick 1985, Cromwell, Avary and Olson 1990, Shover 1991). Second, the importance of insufficient or partial coverage of households was identified (Repetto 1974, Winchester and Jackson 1984, Bureau of Justice Statistics 1983, Rengert and Wasilchick 1985, Cromwell, Avary and Olson 1990, Shover 1991). Third, security quality was low and it was easily overcome - windows and door were 'jimmied', frames and single-pane glass easily broken to gain entry (Repetto 1974, Winchester and Jackson 1984, Bureau of Justice Statistics 1983, Rengert and Wasilchick 1985, Cromwell, Avary and Olson 1990, Shover 1991). Fourth, even where decent security existed, doors and windows were often left unlocked as detailed by (Repetto 1974, Bureau of Justice Statistics 1983, Winchester and Jackson 1984, Rengert and Wasilchick 1985, Cromwell, Avary and Olson 1990, Shover 1991). In addition, there was evidence that while displacement used to be easy when many insecure households were available as alternative targets (Bennett and Wright 1984, Rengert and Wasilchick 1985, Shover 1991), it became more difficult and less likely to occur as households became more secure (Nee 2006). The major change over time in the average age of burglars is consistent with the expected effect of improved household security in reducing the involvement of juveniles more than older offenders.

Table 1. Household security problems and solutions

\begin{tabular}{lll}
\hline \multicolumn{1}{c}{$\begin{array}{c}\text { Security } \\
\text { Issue }\end{array}$} & \multicolumn{1}{c}{ Problem in 1960s-70s } & \multicolumn{1}{c}{ Solution by 2000s } \\
\hline Prevalence & $\begin{array}{l}\text { Many households with little or no } \\
\text { security }\end{array}$ & $\begin{array}{l}\text { Increased retrofit; built-in security in } \\
\text { new homes }\end{array}$ \\
$\begin{array}{l}\text { Partial } \\
\text { coverage }\end{array}$ & $\begin{array}{l}\text { Variation within households e.g. } \\
\text { good door locks but only window } \\
\text { catches }\end{array}$ & $\begin{array}{l}\text { All access points secured; built-in } \\
\text { locks and better materials throughout }\end{array}$ \\
Quality & $\begin{array}{l}\text { Easily-forced locks; single pane } \\
\text { vulnerable glass; weak frames }\end{array}$ & $\begin{array}{l}\text { Deadlocks; integrated locks; stronger } \\
\text { frames; better lighting; storm } \\
\text { windows }\end{array}$ \\
& $\begin{array}{l}\text { Leaving doors and windows } \\
\text { open/unlocked }\end{array}$ & $\begin{array}{l}\text { Closed and locked becomes default } \\
\text { Use }\end{array}$ \\
& $\begin{array}{l}\text { Thwarted offender easily finds less } \\
\text { secure household }\end{array}$ & $\begin{array}{l}\text { Fewer insecure households to move } \\
\text { to }\end{array}$ \\
\hline
\end{tabular}


The means by which it is suggested security improvements were achieved over time are summarized in the third column of Table 1. As the market for household security expanded, it brought new buyers and sellers, stimulating more and better security technologies (with stronger materials and more resistant locks). Over time, as competition and economies of scale lowered per-unit prices, previously 'special' security devices became widely adopted routine precautions (Felson and Clarke 1993). This is consistent with a product lifecycle as demand increases, and with the nature of the diffusion of technology (Rogers 1962). As the prevalence of security increased, so too did its quality and coverage, its routine use, and the use of combinations of devices at the same household. Over time, households became increasingly likely to include integrated deadlocks and locks in doors and windows which had stronger frames, multiple panes of more resistant glass, and other built-in security devices. This made crime displacement increasingly difficult, burglars needing more time and expertise to locate and enter fewer insecure households.

By the third decade of the $21^{\text {st }}$ century, the problem of burglary has been significantly addressed, but is far from solved. An increasing proportion of households are more secure by default. This is evident in how different security devices work in different ways, the more dramatic effect of multiple devices, and the aging of burglars as household security improved.

While the pace and extent of change to household security will have varied significantly from one region, city, town or area to the next and in many instances from one household to the next, such variation would be around a national mean. Further research to identify such variation has the potential to shed significant further light upon, and perhaps to confirm or refute, the findings of the present study.

It is clear that some types of security device are more effective than others. Effectiveness will also vary between brands and product specification for different types of device: this was reported by offenders in relation to locks (some avoiding 'difficult' locks such as 'Chubbs'). With respect to particular devices, the evidence suggests stronger door and windows panels, frames and locks and security lighting are effective, but alarms ineffective, and such nuances are important in relation to implications for the security industry.

Security, insurance and housing industry records are potentially rich sources of information on security product sales by types, model and make, the Standards and tests required, and the history of the evolution of devices: Churchill (2015) and others demonstrate the value of researching the history of security. Industry records may indicate sales of particular locks and types of windows, doors and materials. Archival research and the examination of the timing and nature of lock and security light patents may provide useful indicators of change over time.

Further investigation of the best ways to promote the development and implementation of security would seem appropriate. This indicates the need for further incentivization of industry including but not limited to the construction industry, security device and fittings manufacturers and the home insurance industry. In addition to measures to address burglary, this approach may prove fruitful in relation to industry whose products and work affects a wide range of crime types (Tilley 2018). 


\section{Conclusion}

This study offers an evidence-based explanation for a major social phenomena that was previously unexplained: an 80 percent decline in US residential burglary spanning four decades. It examined the burglary research literature spanning five decades and found that a remarkably consistent picture emerged. Almost as remarkable was the lack of identifiable contrary evidence. The main conclusion of this study is that household security improvements played a central role in the long-term decline in US residential burglary.

The study also concludes, based on the evidence, that five aspects of household security change were important: (1) the increased prevalence of security, (2) better quality, that is more robust and effective, security devices and fittings, (3) increasingly uniform security coverage within households, (4) greater routine use of security devices, and, (5) the reduced likelihood of offender displacement as a consequence. The relative importance of these features is something that future research might examine.

This study approached the subject chronologically. This facilitated a reinterpretation of the burglary literature, reconciling seemingly diverse findings. While the earlier burglary literature had little positive to say about household security, more recent studies made clear that even older expert burglars now have a begrudging respect.

The study identified the disproportionate impact of security improvements upon crime by younger offenders as central. This suggests promising avenues for juvenile crime and justice research. Put simply, making crime a bit more difficult to commit may be the best way to reduce juvenile crime and progression to adult crime. In the long-term, this would reduce juvenile and adult justice costs as fewer offenders entered the systems. To suggest that reducing crime opportunities is likely to be the most effective means of reducing juvenile crime and criminal careers is, of course, quite a significant challenge to orthodox views on this topic and on crime in general. At minimum however, the study indicates that the consideration of the role of security, and of reducing crime opportunities more generally, should be more central in crime theories, research and policy than it is at present.

Household security in the US and elsewhere is likely to continue to improve, reflecting housing market expansion and churn as older homes are replaced or refurbished, and as economies of scale and competition further reduce the prices of security fixtures and fittings. The growth of smart security suggests the possibility for new offender means of entry to households using hacking and social engineering. Assuming smart security overcomes such threats and is effective, it should also decline in price and become more widespread. This all suggest that the next generation of crime research should consider more adequately measuring security of different types in different sectors of society. 


\section{References}

Addington, L. A. and C. M. Rennison. 2013. Keeping the barbarians outside the gate? Comparing burglary victimization in gated and non-gated communities, Justice Quarterly, 32(1); 168-192.

Armitage, R. 2013. Crime Prevention Through Housing Design: Policy and Practice. London: Palgrave Macmillan.

Armitage, R. 2018. Burglars' take on crime prevention through environmental design (CPTED): reconsidering the relevance from an offender perspective. Security Journal, 31(1); 285304.

Armitage, R. and L. Monchuk. 2011. Sustaining the crime reduction impact of designing out crime: Re-evaluating the Secured by Design scheme 10 years on. Security Journal, 24(4); 320-343.

Bässmann, J. (2011). Vehicle Theft Reduction in Germany: The Long-Term Effectiveness of Electronic Immobilisation. European Journal of Criminal Policy Research 17. pp.221246.

Bastion, L. D. (1992). Crime and the Nation's Households, 1991. Bureau of Justice Statistics Bulletin. Washington D.C.: Bureau of Justice Statistics, U.S. Department of Justice.

Beaton, A., M. Cook, M. Kavanagh and C. Herrington. 2000. The psychological impact of burglary, Psychology, Crime \& Law, 6: 33-43.

Bennett, T. and R. Wright. (1984). Burglars on Burglary. Aldershot: Gower.

Biderman, A. D. and J. P. Lynch. (1991). Understanding Crime Incidence Statistics: Why the UCR Diverges from the NCS. New York: Springer-Verlag.

Blumstein, A., J. Cohen, J. A. Roth, and C. A. Visher. (Eds.). (1986). Criminal Careers and Career Criminals (Vol. I). Washington D.C.: National Academy Press.

Bowers, K. and S.D. Johnson. 2017. Burglary prevention in practice. In N. Tilley and A. Sidebottom (eds). Handbook of Crime Prevention and Community Safety, $2^{\text {nd }}$ edition. London/New York: Routledge. (pp. 319-353)

Brown, B. B. and Harris, P. B. (1989). 'Residential burglary victimization: Reactions to the invasion of a primary territory', Journal of Environmental Psychology, 9; 119-132.

Brown, R. (2015a). Reviewing the effectiveness of electronic vehicle immobilisation: Evidence from four countries. Security Journal, 28(4): 329-351.

Brown, R. (2015b). Explaining the property crime drop: the offender perspective. Trends and Issues in Crime and Justice No. 495. Canberra: Australian Institute of Criminology.

Bureau of Justice Statistics. (1985). Household Burglary. Bureau of Justice Statistics Bulletin. Washington D.C.: Bureau of Justice Statistics, U.S. Department of Justice. 
Budd, T. (1999). Burglary of Domestic Dwellings: Findings from the British Crime Survey. Home Office Statistical Bulletin 04/99. London: Home Office.

Clarke, R.V. (2012). Opportunity makes the thief. Really? And so what? Crime Science, 1(2); 19.

Clarke, R.V. 2017. Situational crime prevention. In R. Wortley and M. Townsley (Eds.) Environmental Criminology and Crime Analysis, $2^{\text {nd }}$ edition. London: Routledge.

Churchill, D. 2016. The spectacle of security: lock picking competitions and the security industry in mid-Victorian Britain. History Workshop Journal, 80(1); 52-74.

Cohen, L. E. and M. Felson. 1979. 'Social change and crime rate trends: A routine activity approach, American Sociological Review, 44(4): 588-608.

Cohen, M. A. 2000. 'Measuring the Costs and Benefits of Crime and Justice', Measurement and Analysis of Crime and Justice, Vol. 4 of Criminal Justice 2000, Washington DC: National Institute of Justice.

Cromwell, P. F., Olson, J. N. and Avary, D. W. (1991). Breaking and Entering: An Ethnographic Analysis of Burglary. Newbury Park: Sage.

Farrell, G. 2013. 'Five tests for a theory of the crime drop' Crime Science 2(5); 1-8.

Dixon, A. and G. Farrell. 2020. (2020). Age-period-cohort effects for half a century of motor vehicle theft in the United States, Crime Science, 9(11); 1-17.

Farrell, G., N. Tilley and A. Tseloni. (2014). 'Why the crime drop?' in M. Tonry (Ed.) Why Crime Rates Fall and Why They Don't, volume 43 of Crime and Justice: A Review of Research. Chicago: University of Chicago Press. (pp. 421-490).

Farrell, G., Tseloni, A., Mailley, J. and Tilley, N. (2011). The crime drop and the security hypothesis Journal of Research in Crime and Delinquency, 48(2); 147-175.

Farrington, D. P. (1986). Age and crime. In M. Tonry and N. Morris (Eds.) Crime and Justice: An Annual Review of Research. (pp. 189-251). Chicago: University of Chicago Press.

Felson, M. and R.V. Clarke 1995. Routine precautions, criminology and crime prevention. In H.D. Barlow (ed.) Crime and Public Policy. New York: Springer Verlag (pp. 120-128).

Felson, M. and R.V. Clarke. 1998. Opportunity Makes the Thief: Practical Theory for Crime Prevention. Police Research series paper 98. London: Home Office.

Fujita, S., and M. Maxfield. (2012). Security and the drop in car theft in the United States. in J .J. M. vachenen Dijk, Tseloni, A. and Farrell, G. (Eds). The International Crime Drop: New Directions in Research. Palgrave Macmillan.

Grove, L. E., Farrell, G. Farrington, D. P. and Johnson, S. D. (2012). Preventing Repeat Victimization: A Systematic Review. Stockholm: Swedish National Council for Crime Prevention. 
Guerette, R. T. and K. J. Bowers. (2009). Assessing the extent of crime displacement and diffusion of benefits: A review of situational crime prevention evaluations. Criminology 47(4):1331-68.

Kriven, S. and Ziersch, E. (2007). New Car Security and Shifting Vehicle Theft Patterns in Australia. Security Journal, 20:111-22.

Lauritsen, J. L., Rezey, M. L. and Heimer, K. (2016). When choice of data matters: Analyses of U.S. crime trends, 1973-2012. Journal of Quantitative Criminology, 32: 335-355.

Lee, S. and H. Wilson. 2013. Spatial impact of burglary alarms on the decline of residential burglary, Security Journal, 26(2); 180-198.

Lynch, J. P. and Addington, L.A. (2007). Understanding Crime Statistics: Revisiting the Diverge of the NCVS and UCR. New York: Cambridge University Press.

Macmillan, R. (2000). 'Adolescent victimization and income deficits in adulthood: rethinking the costs of criminal violence from a life course perspective', Criminology 38:553-88.

Maguire, M. and Bennett, T. (1982). Burglary in a Dwelling: The Offence, the Offender and the Victim. London: Heinemann.

Mayhew, P. (1987). Residential Burglary: A Comparison of the United States, Canada and England and Wales. Washington D.C.: Department of Justice, National Institute of Justice.

Maxfield, M. 1987. Lifestyle and routine activity theories of crime: Empirical studies of victimization, delinquency and offender decision-making, Journal of Quantitative Criminology, 3(4); 275-282.

Mawby, R. I. 2001. Burglary. Portland: Willan.

Miller, T. R., M. A. Cohen and B. Wiersema. (1996). Victim Costs and Consequences: A New Look. Washington D.C.: Department of Justice, National Institute of Justice.

Nee, C. 2015. 'Understanding expertise in burglars: From pre-conscious scanning to action and beyond', Aggression and Violent Behavior, 20; 53-61.

Nee, C. and A. Meenaghan. 2006. Expert decision-making in burglars. British Journal of Criminology, 46; 935-949.

Owen, N., and C. Cooper. 2013. The start of a criminal career: does the type of debut offence predict future offending?. London: Home Office.

Pease, K. 1991. 'The Kirkholt Project: Preventing burglary on a British public housing estate' Security Journal, 2(2); 73-77.

Piquero, A. and S. Tibbetts. (Eds.). 2002. Rational Choice and Criminal Behavior. New York: Routledge.

President's Commission on Law Enforcement and Administration of Justice. (1967). The Challenge of Crime in a Free Society. Washington DC: Government Printing Office. 
Rand, M. R., Lynch, J. P. \& Cantor, D. (1997). Criminal Victimization, 1973-1995. Washington D.C.: Bureau of Justice Statistics, U.S. Department of Justice Office of Justice Programs. (NCJ-163069).

Reppetto, T. A. (1974). Residential Crime. Cambridge, MA.: Ballinger.

Reppetto, T. A. (1984). 'Police anti-burglary strategies in the United States' in R.Clarke and T. Hope (Eds.) Coping with Burglary. Boston: Kluwer-Nijhoff. (pp.155-167).

Rengert, G. and Wasilchick, J. (1985). Suburban Burglary: A Time and a Place for Everything. Illinois: Charles C. Thomas.

Rogers, E. M. Diffusion of Innovations. (New York: Free Press, 1962).

Sampson, R. (2007). False Burglar Alarms, Second Edition. Problem Specific Guide No. 5. Washington D.C.: Community Oriented Policing Services.

Shover, N. (1991). Burglary, Crime and Justice, 14; 73-113.

Snyder, H. (2012). Arrest in the United States 1990-2010. Washington D.C.: Bureau of Justice Statistics. (NCJ 239423).

Sorensen, D. (2003). The Nature and Prevention of Residential Burglary: A Review of the International Literature with an Eye Toward Prevention in Denmark. Faculty of Law, University of Copenhagen.

Snyder, H., Cooper, A. D., Mulako-Wangota, J. (2017). Arrest in the United States, 1980-2014. Generated using the Arrest Data Analysis Tool at www.bjs.gov (06 October 2018).

Thomson, I. (2016). 'If you use 'smart' Bluetooth locks you're asking to be burgled' The Register, 08 August 2015, at http://www.theregister.co.uk/2016/08/08/using_a_smart_bluetooth_lock_to_protect_your _valuables_youre_an_idiot/, accessed 10 August 2016.

Tilley, N. (2018) 'Privatising crime control.' Annals of the American Academy of Political and Social Science. 679 (1), 55-71.

Tilley, N., Tseloni, A. and Farrell, G. (2011). 'Income disparities of burglary risk: Security availability during the crime drop' British Journal of Criminology, 51, 296-313.

Tilley, N., Farrell, G. and Clarke, R V. (2015a). 'Target suitability and the crime drop' in M. Andresen and G. Farrell (Eds.) Routine Activities and the Criminal Act. London: Palgrave Macmillan. pp. 59-76.

Tilley, N., Farrell, G., Grove, L. E., Thompson, R. and Tseloni, A. (2015b). 'Do burglar alarms increase burglary risk? A counterintuitive finding and possible explanation' Crime Prevention and Community Safety: An International Journal, 17(1);1-19.

Tonry, M. (2014). Why crime rates are falling throughout the western world. Crime and Justice, 43: $1-63$.

Tseloni, A., Mailley, J., Farrell, G. and Tilley, N. (2010). 'Exploring the international decline in crime rates', European Journal of Criminology, 7(5); 375-394. 
Tseloni, A., Thompson, R., Grove, L. E., Tilley, N. and Farrell, G. (2016). The effectiveness of burglary security devices, Security Journal, 30(2); 646-664.

Tseloni, A., Farrell, G., Thompson, R., Evans, E., Grove, L. E. and Tilley, N. (2017). Domestic burglary drop and the security hypothesis, Crime Science, 6(3); 1-16.

U.S. Census Bureau. (2018). Current Population Survey, March and Annual Social and Economic Supplements. (At https://www.census.gov/programs-surveys/cps/technicaldocumentation/complete.html accessed 30 October 2018.)

Van Dijk, J. J. M. (2008). The World of Crime. London: Sage.

Van Ours, J. C. and B. Vollaard. (2016). The Engine Immobiliser: A Non-starter for Car Thieves, Economic Journal, 126(593): 1264-1291.

Vollaard, B. and J. C. van Ours. (2011). Does regulation of built-in security reduce crime? Evidence from a natural experiment. Economic Journal, 121(552); 486-504.

Waller, I. and Okihiro, N. (1978). Burglary: The Victim and the Public. Toronto: University of Toronto Press.

Wickramasekera, N., Wright, J., Elsey, H., Murray, J and Tubeauf, S. (2015). Cost of crime: A systematic review. Journal of Criminal Justice, 43; 218-228.

Walters, J.H., A. Moore, M. Berzofsky, and L. Langton. 2013. Household Burglary 1994-2011. Washington D.C.: Nureau of Justice Statistics.

Wilcox, P., T. D. Madensen and M. Skubak Tillyer. 2007. Guardianship in context: Implications for burglary victimization risk and prevention, Criminology, 45(4): 771-803.

Winchester, S. and Jackson, H. (1982). Residential Burglary: The Limits of Prevention. Home Office Research Study No. 74. London: Her Majesty's Stationery Office.

Winkel, F. W. and A. Vrij. 1993. Facilitating problem- and emotion-focused coping in victims of burglary: Evaluating a police crisis intervention program, Journal of Community Psychology, 21(2); 97-112.

Wolpin, S. (2016). 5 best smart locks for your home, Techlicious, at http://www.techlicious.com/guide/5-futuristic-smart-locks-for-your-home/ accessed 10 August 2016.

Wright, R. W. and S. Decker. (1994). Burglars on the Job: Streetlife and Residential Break-Ins. Boston: Northeastern University Press. 


\section{Endnotes}

${ }^{1}$ The National Crime Victimization Survey (NCVS) is the most reliable source on residential burglary trends, measuring it from 1973 onwards, while burglaries reported to and recorded by the police, collated nationally by the FBI as the Uniform Crime Reports (UCR) are available for longer. The trends track each other reasonably well over time (Biderman and Lynch 1990; Lynch and Addington 2008; Lauritsen, Rezey and Heimer 2016). The household rates used here are based on the number of households estimated by the US Census Bureau.

${ }^{2}$ Readers should note that the decline in burglary in the UK began at least a decade later than in the US. This suggests that British studies from the 1980s may be more comparable, in terms of the prevailing burglary trend, to those from the US in the 1970s.

${ }^{3}$ One interpretation is that the proportion of secure targets in a population really determines what is sometimes called collective efficacy. 